\title{
An Arctic CCN-limited cloud-aerosol regime
}

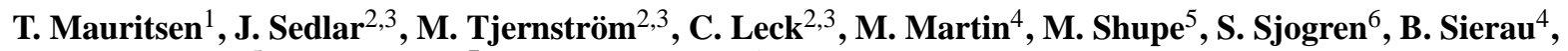 \\ P. O. G. Persson ${ }^{5}$, I. M. Brooks ${ }^{7}$, and E. Swietlicki ${ }^{6}$
}

${ }^{1}$ Max Planck Institute for Meteorology, Hamburg, Germany

${ }^{2}$ Bert Bolin Center for Climate Research, Stockholm, Sweden

${ }^{3}$ Stockholm University, Stockholm, Sweden

${ }^{4}$ Institute for Atmospheric and Climate Science, ETH Zurich, Zurich, Switzerland

${ }^{5}$ University of Colorado and NOAA-ESRL, Boulder, Colorado, USA

${ }^{6}$ Lund University, Lund, Sweden

${ }^{7}$ University of Leeds, Leeds, UK

Received: 18 June 2010 - Published in Atmos. Chem. Phys. Discuss.: 6 July 2010

Revised: 8 December 2010 - Accepted: 23 December 2010 - Published: 10 January 2011

\begin{abstract}
On average, airborne aerosol particles cool the Earth's surface directly by absorbing and scattering sunlight and indirectly by influencing cloud reflectivity, life time, thickness or extent. Here we show that over the central Arctic Ocean, where there is frequently a lack of aerosol particles upon which clouds may form, a small increase in aerosol loading may enhance cloudiness thereby likely causing a climatologically significant warming at the ice-covered Arctic surface. Under these low concentration conditions cloud droplets grow to drizzle sizes and fall, even in the absence of collisions and coalescence, thereby diminishing cloud water. Evidence from a case study suggests that interactions between aerosol, clouds and precipitation could be responsible for attaining the observed low aerosol concentrations.
\end{abstract}

\section{Introduction}

Airborne aerosol particles cool the Earth's surface on average, both directly by absorbing and scattering sunlight and indirectly by influencing cloud reflectivity, life time, thickness or extent (Twomey, 1977; Albrecht, 1989; Solomon et al., 2007). Clouds both cool the surface by reflecting sunlight (shortwave) and warm it by emitting infrared radiation (longwave), relative to an otherwise identical, but cloud-free atmosphere. We define the cloud forcing, or cloud radiative effect, formally following Schneider (1972):

$\mathrm{CF}=F-F_{\text {clear }}$,

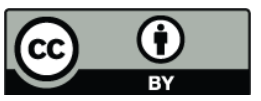

Correspondence to: T. Mauritsen (thorsten.mauritsen@zmaw.de) where $F$ is the sum of the net observed long- and shortwave radiative fluxes at a height level of interest, while $F_{\text {clear }}$ is what those fluxes would have been in a cloud-free atmosphere. Cloud forcing may be defined at any atmospheric level, and clouds may also impact turbulent fluxes. Globally, the net effect of clouds at the top of the atmosphere is to cool the planet (Schneider, 1972; Ramanathan et al., 1989), whereas they act to warm the surface in the Arctic (Walsh and Chapman, 1998; Intrieri et al., 2002).

Cloud formation relies on both the presence of sufficient water vapor and cloud condensation nuclei $(\mathrm{CCN})$, a subset of the aerosol particle population that activate to form cloud droplets at a given water vapor supersaturation (Köhler, 1936). Aerosol-induced cloud modifications are thought to affect climate in several ways. The first aerosol indirect effect, also known as the cloud-albedo or Twomey-effect, states that an increase in $\mathrm{CCN}$ leads to more cloud droplets of smaller size, yielding more reflective clouds, provided the total cloud liquid content is unchanged (Twomey, 1977). Though found to be negligible at the global scale (Rotstayn and Penner, 2001), observations from the Arctic suggest that cloud droplet radius alone can also significantly impact longwave cloud forcing at the surface by altering the cloud emissivity (Curry and Herman, 1985; Curry, 1992, 1995; Garrett et al., 2002; Lubin and Vogelmann, 2006; Garrett and Zhao, 2006). The second aerosol indirect effect - the cloud life-time or Albrecht-effect - involves aerosol particles altering the cloud macro-structure (Albrecht, 1989; Pincus and Baker, 1994; Curry, 1995). Accordingly, an increase in aerosol concentration yields (1) more abundant and smaller cloud droplets, that (2) take longer to grow to precipitation sizes through collisions, (3) increasing cloud life-time, extent and/or liquid water path. The processes comprising the

Published by Copernicus Publications on behalf of the European Geosciences Union. 
second aerosol indirect effect and potential feedbacks between them are complex, hindering our understanding, while evidence of their impact on climate remains controversial (Ackermann et al., 2004; Lu and Seinfeld, 2005; Rosenfeld et al., 2008; Sandu et al., 2008; Stevens and Feingold, 2009).

Observed CCN number concentrations over the central Arctic Ocean are usually lower than 100 per cubic centimeter $\left(\mathrm{cm}^{-3}\right.$ ), occasionally less than $1 \mathrm{~cm}^{-3}$ (Lannerfors et al., 1993; Bigg et al., 1996; Bigg and Leck, 2001; Leck et al., 2002), which is orders of magnitude less than at lower latitudes where typical concentrations range from hundreds to thousands per $\mathrm{cm}^{3}$ (Ramanathan et al., 2001). At very low $\mathrm{CCN}$ number concentrations, cloud formation - and therefore cloud radiative forcing - must be limited by the $\mathrm{CCN}$ available. In a hypothetical atmosphere without aerosol particles clouds will not form, except at very high supersaturations. In an atmosphere with sufficient aerosol and moisture, clouds can form and therefore exert a radiative forcing. Between these two states, a regime must exist where cloud formation, and hence the cloud forcing, is limited by the available CCN. Within this tenuous cloud regime, cloud liquid content can be limited by the relatively low concentration of activated liquid droplets, which reduces opportunities for vapor deposition and causes the few activated droplets to grow to relatively large sizes that fall under gravity. Droplet fall velocity increases approximately with the square of the radius. Marine stratocumulus clouds are often found to exhibit a threshold in the cloud droplet distribution effective radius $\left(R_{\mathrm{e}}\right)$, typically around $15 \mu \mathrm{m}$, which must be exceeded before drizzle occurs (Gerber, 1996; Garrett et al., 2002). In a given cloud droplet size distribution, it is primarily the largest droplets that fall out. The proposed CCN-limited tenuous cloud regime is formally considered a second aerosol indirect effect; most previous studies on the Arctic have focussed on quantifying the first aerosol indirect effect (Curry and Herman, 1985; Curry, 1992, 1995; Garrett et al., 2002; Lubin and Vogelmann, 2006; Garrett and Zhao, 2006; Lubin and Vogelmann, 2007).

\section{Observations and model description}

Observational data used in this study were obtained during the Arctic Summer Cloud Ocean Study (ASCOS) from the central Arctic Ocean during August to mid-September of 2008. ASCOS was designed to study processes relevant for the formation and life cycle of low-level clouds in the central Arctic Ocean, including suggested linkages to particulate matter originating in microbiological life in the ocean and ice (Leck and Bigg, 2008). ASCOS was therefore organized to include oceanography, marine biochemistry, particulate and gas phase physics and chemistry and meteorological measurements. The experiment was carried out onboard the Swedish icebreaker Oden, and included a three week deployment of instruments on a drifting ice floe. The cruise track

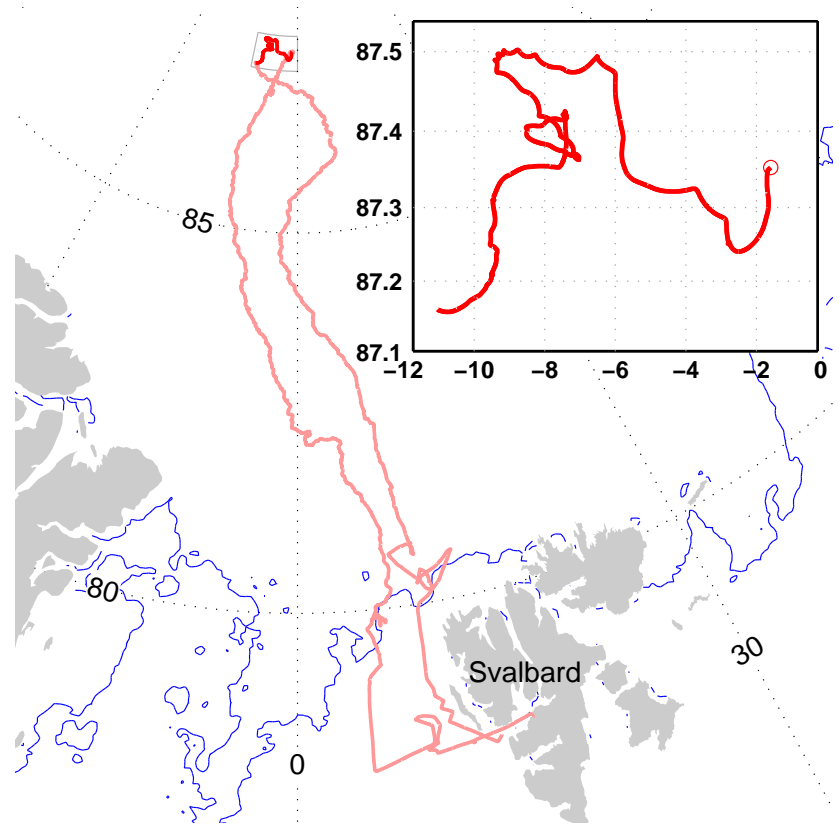

Fig. 1. Cruise track of ASCOS shown in red with the ice-drift in the insert. Thin blue line is the observed ice edge on 12 August 2008.

and ice drift is shown in Fig. 1. ASCOS was the fourth in a series of expeditions in approximately the same region carried out in 1991 (IAOE-91 (Leck et al., 1996), 1996 (AOE96 Leck et al., 2001) and 2001 (AOE-2001 Leck et al., 2004; Tjernström et al., 2004).

Observations of long- and shortwave fluxes were obtained during ASCOS using broadband radiometers deployed on an ice floe in the period 13 August to 1 September 2008. Because it was almost always cloudy, the clear-sky radiative fluxes are calculated with a radiation transfer model (Fu and Liou, 1992) using temperature and humidity from 6-hourly radiosoundings interpolated in time to each hour, a fixed ozone-profile and fixed carbon-dioxide and methane concentrations (Intrieri et al., 2002; Sedlar et al., 2010). No background aerosol profile was used for the clear-sky calculations, which is likely to systematically bias the cloud forcing high when clouds are thin. We estimate the random error on the cloud forcing is less than $\pm 10 \mathrm{Wm}^{-2}$, which is due to measurement, interpolation and radiation transfer calculation errors. Cloud radar reflectivity was obtained using a Kband millimeter wavelength cloud radar (Moran et al., 1998). $\mathrm{CCN}$ were measured with two identical in situ CCN counters (Roberts and Nenes, 2005). One counter had a constant supersaturation of $0.2 \%$, while the other counter was cycled between 0.1 and $0.7 \%$. The former instrument was used to obtain CCN number concentrations and the latter was used to identify cases when the $\mathrm{CCN}$ number concentration estimate was particularly sensitive to the choice of supersaturation.

Idealized cloud calculations are performed using a single temperature and humidity profile measured during ASCOS 
and a standard radiation transfer model ( $\mathrm{Hu}$ and Stamnes, 1992; Key and Schweiger, 1998). The shortwave surface reflectivity (albedo) was set at 0.8 and the solar zenith angle was held fixed, both chosen to match the ASCOS experiment mean conditions; the surface longwave emissivity was set to unity. A single, low-level stratus cloud is used. The cloud top was held at $900 \mathrm{~m}$ and cloud base at $565 \mathrm{~m}$, to yield an initial liquid water path of $67 \mathrm{gm}^{-2}$, the ASCOS median value as measured by a microwave radiometers (Westwater et al., 2001). We relate the cloud liquid water content (LWC) to $R_{\mathrm{e}}$ by assuming spherical droplets and a lognormal droplet size distribution:

$\mathrm{LWC}=\mathrm{CCN} \cdot \frac{4}{3} \rho \pi R_{\mathrm{e}}^{3} \cdot e^{-3 \sigma^{2}}$,

where $\rho$ is the density of water and $\sigma$ is the non-dimensional width of the lognormal distribution set here to 0.32 . The cloud droplet number concentration is assumed to equal the CCN concentration assuming that no droplet collisions or coalescence occur. LWC is initially set to $0.2 \mathrm{gm}^{-3}$, a typical value for low-level Arctic clouds (Curry, 1986; Verlinde et al., 2007; Shupe et al., 2008). Given LWC and CCN, $R_{\mathrm{e}}$ is calculated by rearranging Eq. (2). In cases when the cloud liquid is limited by a specified threshold value of $R_{\mathrm{e}}$, Eq. (2) is used directly to calculate LWC, given CCN. LWC and $R_{\mathrm{e}}$ are used by the radiation transfer code to calculate the cloud radiative forcing.

\section{Results}

We perform idealized radiative transfer calculations to estimate the cloud forcing in the $\mathrm{CCN}$-limited regime originating from a single low-level all-liquid stratus cloud under typical conditions experienced during the ASCOS experiment. Two scenarios are investigated. Firstly, the cloud liquid content is held fixed while varying the $\mathrm{CCN}$ concentration, resulting in changes to $R_{\mathrm{e}}$ in accordance with the first aerosol indirect effect. Secondly, the cloud liquid water is deposited whenever a threshold value in $R_{\mathrm{e}}$ of $15 \mu \mathrm{m}$ is reached, thereby emulating fallout by drizzle and allowing aerosols to influence the cloud liquid water path, representing the second aerosol indirect effect.

Both scenarios exhibit dependencies on $\mathrm{CCN}$ in both longand shortwave surface cloud radiative forcing (Fig. 2, thick lines). For $\mathrm{CCN}>10 \mathrm{~cm}^{-3}$ the longwave cloud radiative forcing is approximately constant in both scenarios; here the cloud radiates as a nearly ideal black body. At the same time the shortwave cloud forcing is increasingly negative in agreement with the Twomey-effect (Twomey, 1977). At lower CCN concentrations the two scenarios differ. The longwave cloud forcing associated with the first indirect effect decreases by approximately $20 \mathrm{Wm}^{-2}$ as CCN concentration drops to $0.3 \mathrm{~cm}^{-3}$, while in the $\mathrm{CCN}$-limited scenario cloud forcing decreases by about $70 \mathrm{Wm}^{-2}$ over the same

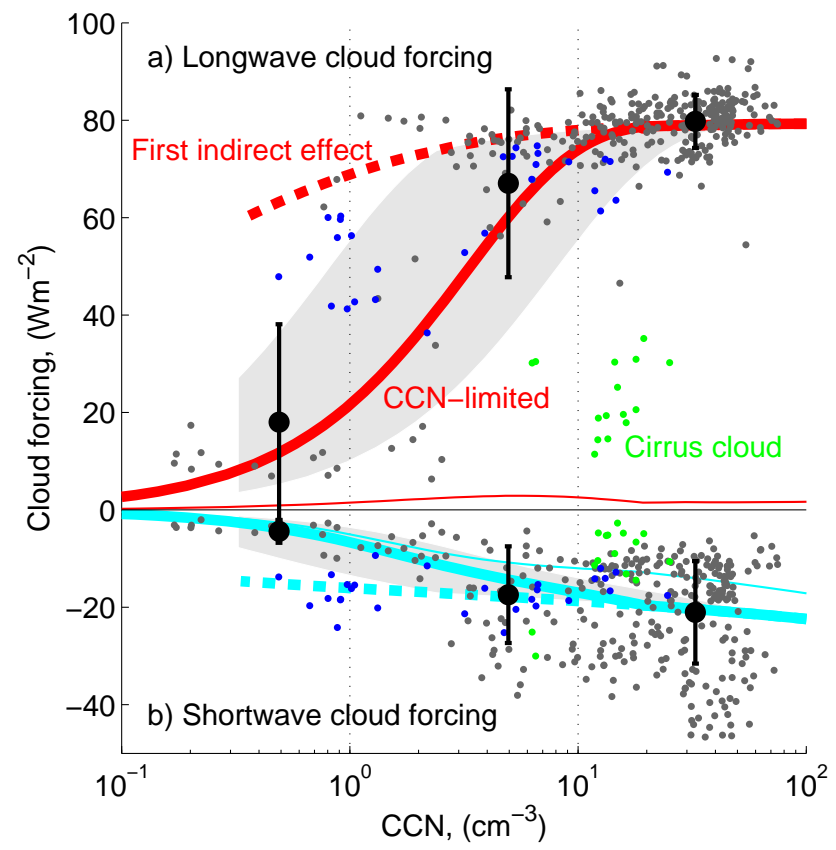

Fig. 2. Surface (a) longwave- and (b) shortwave cloud radiative forcing as a function of $\mathrm{CCN}$ number concentration. $\mathrm{CCN}$ measurements were made at a supersaturation of $0.2 \%$. Dots are hourly observations; lines are idealized radiative transfer calculations described in the text. Dashed lines represent the first aerosol indirect effect only. Solid thick lines correspond to cloud liquid content being limited by $R_{\mathrm{e}} \leq 15 \mu \mathrm{m}$. The grey shaded areas show the sensitivity to critical $R_{\mathrm{e}}$ values between 10 and $30 \mu \mathrm{m}$. Thin solid lines are the long- and shortwave cloud forcing at the top of the atmosphere. Large black dots are bin averaged values for each decade of CCN concentration and bars indicate the standard deviation from the decade mean. Green markers are related to a single case with mid-tropospheric ice clouds that are radiatively very different from a low-level stratus cloud; furthermore, the $\mathrm{CCN}$ concentration measured near the surface is not relevant for these clouds. Blue markers are cases for which the $\mathrm{CCN}$ measurement is particularly dependent on the choice of supersaturation. This is due primarily to a steep cumulative size distribution near the critical size for activation at the supersaturation used.

range. The shortwave cloud forcing displays a similar behavior though of smaller magnitude. The transition value of approximately $10 \mathrm{CCN} \mathrm{cm}^{-3}$ is not universal, as it depends on the choice of parameters.

These findings are compared with estimated cloud radiative forcing from observations obtained during the ASCOS experiment. Three quarters of the hourly CCN number concentrations were greater than $10 \mathrm{~cm}^{-3}$. At these concentrations the agreement between the modeled longwave cloud forcing and the vast majority of observations is striking, despite varying cloud characteristics and a changing background atmosphere. At lower concentrations the observed longwave cloud forcing is highly variable and, at the low end close to the CCN-counter detection limit, 
the observed longwave cloud forcing is reduced to approximately $10 \mathrm{Wm}^{-2}$. Similarly, in the observed CCN range the magnitude of the shortwave cloud radiative forcing increases from near $0 \mathrm{Wm}^{-2}$ to $-40 \mathrm{Wm}^{-2}$. For a given CCN concentration, the magnitude and variability in the shortwave cloud forcing are primarily determined by the solar zenith angle and surface reflectivity.

Note that low-level mixed-phase clouds were observed during ASCOS, despite relatively warm temperatures. Including ice crystals into the calculations introduces a number of uncertainties and assumptions, while sensitivity tests showed that small fractions of ice crystals did not alter the results significantly. It is also worth noting that at the top of the atmosphere the longwave cloud forcing is small since the cloud temperature is close to that of the surface, while the shortwave forcing is only slightly less than at the surface (Fig. 2, thin lines). Hence, the studied aerosol indirect effect is warming the surface, while cooling at the top of the atmosphere. Since CCN were measured at the icebreaker ( $25 \mathrm{~m}$ altitude) and the clouds typically occurred above this height, the representativity of the $\mathrm{CCN}$ measurements for the cloud formation is uncertain; this is particularly true on occasions when the lower atmosphere was stably stratified. The value of supersaturation applied to the $\mathrm{CCN}$-counter is based on typical values set in other studies (Bigg and Leck, 2001; Zhou et al., 2001; Leck et al., 2002; Lohmann and Leck, 2005). One could speculate that higher supersaturations could occur when there is a lack of aerosol upon which water vapor can condense, thereby gradually activating more and more aerosol particles of smaller size and/or lower hygroscopicity. Despite these caveats in interpreting the observations, we believe that the observations of cloud forcing are in fact consistent with the proposed $\mathrm{CCN}$-limited second aerosol indirect effect, and inconsistent with the first aerosol indirect effect alone.

\subsection{Case study}

The ideas presented gain support from our analysis of individual events, the most prominent of which is shown in Fig. 3. It is important to remember that observations are taken at one location and reflect a combination of local processes and horizontal transport. In the evening of 31 August the CCN concentration falls to values below $1 \mathrm{~cm}^{-3}$. Simultaneously, clouds become optically thin, barely detectable by the cloud radar. Both cloud radiative forcing components fall to low values and the surface temperature drops dramatically. During the period of low CCN number concentrations, the accumulation mode particles are correspondingly low (Fig. 3b, e). In the late morning of 1 September, CCN concentrations rise to higher values, the cloud thickens and the surface temperature increases. The observed positive correlation between $\mathrm{CCN}$ concentration and temperature is contrary to the global net effect of aerosol particles, which is to cool the surface (Solomon et al., 2007). The mere pres-
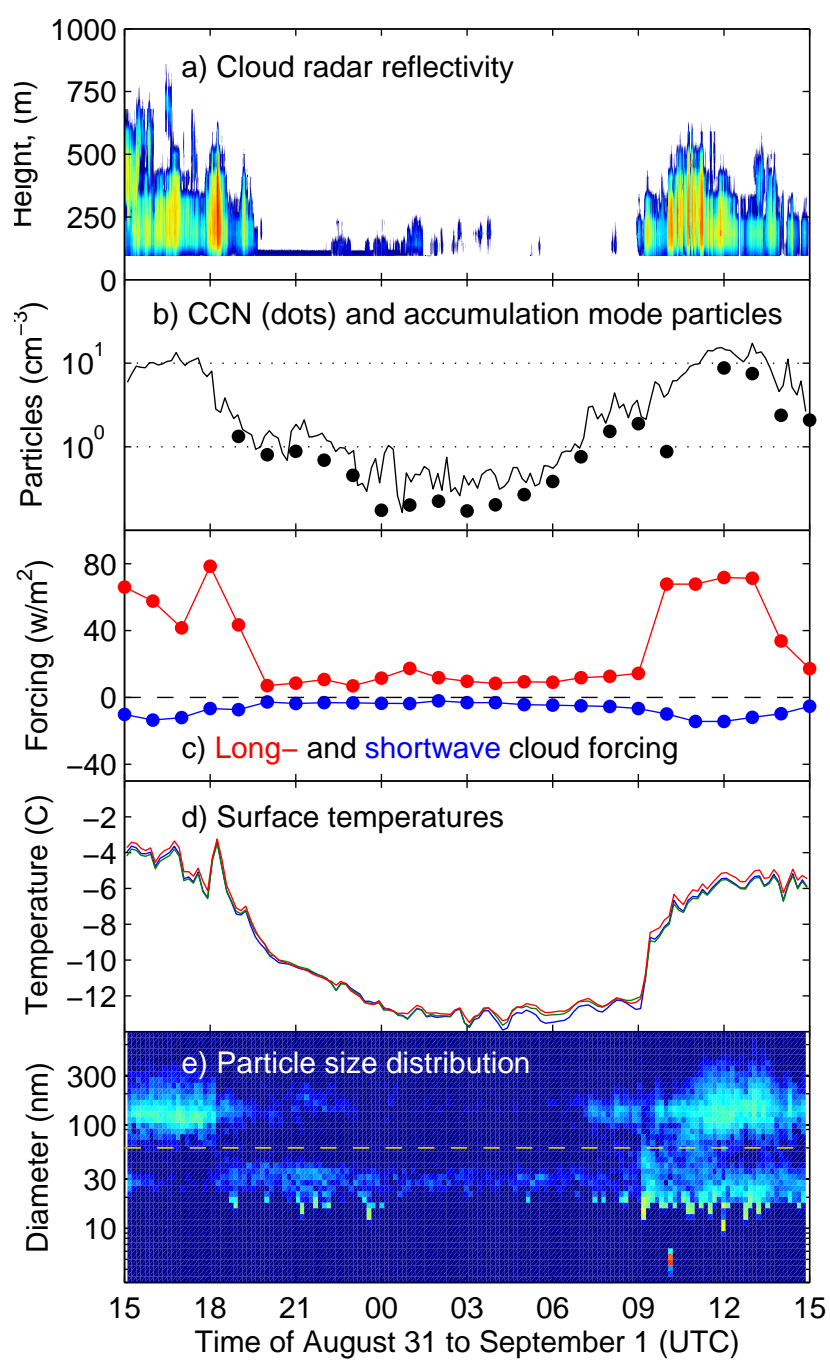

Fig. 3. Evolution of relevant measurements for a case of very low CCN number concentrations. The cloud radar is sensitive to both clouds and precipitation with the lowest measurement height at $105 \mathrm{~m}$. Aerosols larger than approximately $60 \mathrm{~nm}$ are accumulation mode particles, the sum of which is shown in panel (b) as a solid line, while the smaller sized mode seen below the yellow dashed line in panel (e) is the Aitken mode Covert et al. (1996). Aitken mode particles are usually not sufficiently large to be CCN.

ence of a correlation does not necessarily establish a causal relationship; here we propose a plausible physical connection through the second aerosol indirect effect changing the cloud radiative forcing, which alone is sufficient to explain the observed temperature changes.

While our conclusions do not depend on the nature of the sources and sinks controlling CCN, it is interesting how neardepletion of CCN can occur. Shifts in $\mathrm{CCN}$ to low values were not associated with synoptic scale fronts, and they occurred within air masses that had resided more than a week over the Arctic pack ice. Further, the associated cooling was 


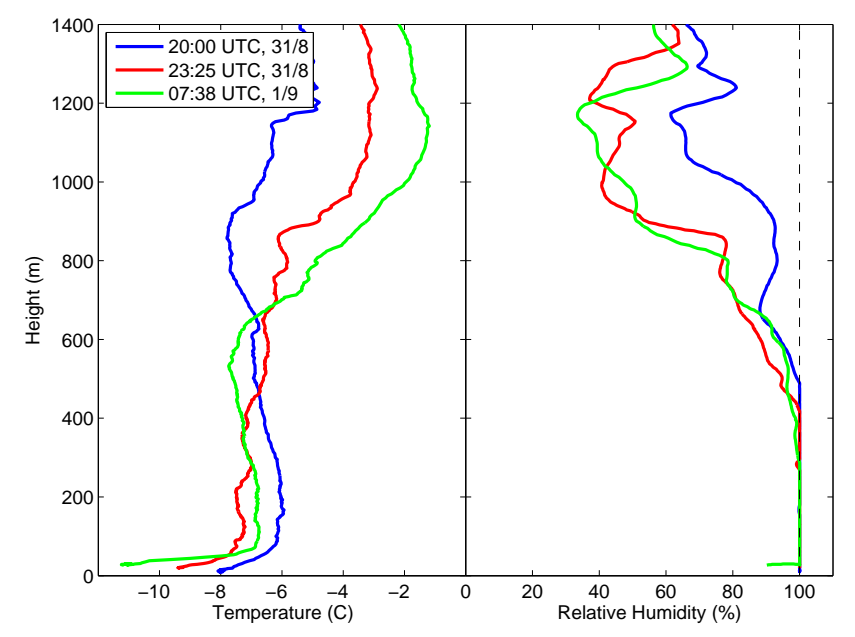

Fig. 4. Profiles of temperature and relative humidity with respect to liquid corresponding to the case shown in Fig. 3.

surface based, and hence not advective, while subsidence occurring during the case was not sufficient to evaporate the cloud as can be inferred from helicopter profiles obtained during the case (Fig. 4). The cooling over time occurs mainly in the lower $50 \mathrm{~m}$ of the atmosphere, and in this case is therefore not likely to be caused by advection of cold air from elsewhere. The progression of the temperature profiles above $600 \mathrm{~m}$ are indicative of subsidence. Slow subsidence such as this could be caused by a synoptic high pressure system, or as a dynamical response to the surface cooling. Either way, the relative humidity remains at saturation with respect to liquid in the lower atmosphere at all times, meaning that subsidence was insufficient to evaporate the cloud. A double fog bow observed at the onset of this event (Fig. 5) reveals the presence of a few large drizzle sized droplets with $R_{\mathrm{e}}$ of 20 $50 \mu \mathrm{m}$ (Lee, 1998) that are barely sensed by the cloud radar. Single colorless bows, which were observed more commonly during the experiment, occur for $R_{\mathrm{e}}$ below $20 \mu \mathrm{m}$.

One compelling interpretation of the evidence is that low aerosol concentration increases precipitation efficiency, in turn providing a positive feedback on the aerosol by increased wet deposition (Baker and Charlson, 1990; Ackermann et al., 1994). It has even been suggested that the presence of mixed-phase clouds may act to strengthen this feedback as ice forming nuclei are relatively more abundant in cleaner air (Curry, 1995). Presumably, the processes underlying the tenuous cloud regime may occur worldwide where cloud formation is inhibited by the lack of $\mathrm{CCN}$, in which context the relation to pockets of open cells (POCs) merits discussion. POCs are observed to be embedded in marine stratocumulus cloud sheets in the sub-tropics (Stevens et al., 2005). POCs appear to be associated with enhanced precipitation and low accumulation mode aerosol concentrations (Petters et al., 2006; Wood et al., 2008). Whereas POCs remain convectively mixed, with the tenuous Arctic clouds

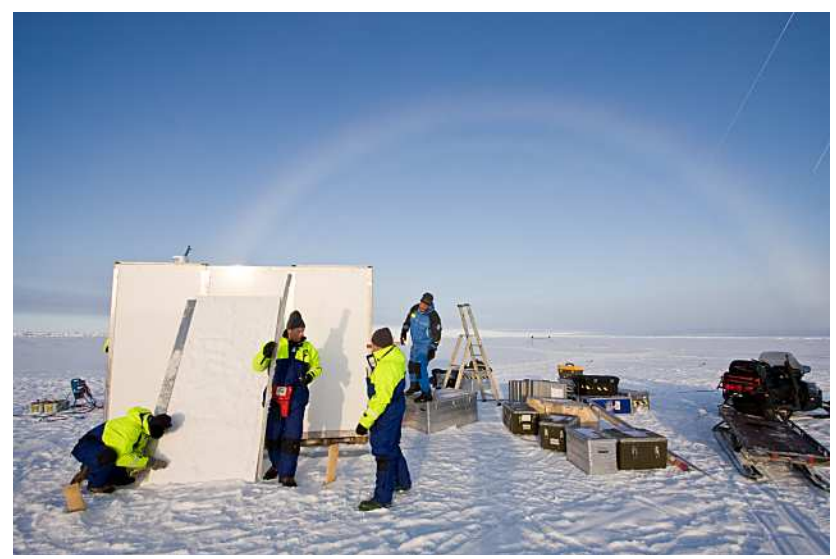

Fig. 5. A rare case of a double fog bow observed on 31 August at 21:21 UTC $\left(87^{\circ} \mathrm{N}\right)$, at the onset of the event shown in Figure 3, reveals the presence of large cloud droplets in the $20-50 \mu \mathrm{m}$ size range. The fog, or cloud, is also visible towards the horizon where the optical thickness along the line of sight becomes increasingly large, or simply reflecting horizontal inhomogeneities.

the boundary layer here becomes stably stratified due to the pronounced associated surface cooling (Fig. 4). The stratification inhibits the vertical transport of water vapor from the surface to the cloud layer, by effectively decoupling the cloud from the surface. It may well be that once formed, this dynamical boundary layer feedback prevents initially tenuous arctic clouds from thickening again. It also helps to explain why precipitation is enhanced in POCs, while appearing to be reduced well within the tenuous cloud regime after the onset as seen by the cloud radar (Fig. 3).

\subsection{Implications for high Arctic climate}

We study the climate impact of a change in the aerosol loading under conditions found during ASCOS. For this purpose, the climatological frequency distribution of $\mathrm{CCN}$ concentrations is important because adding $\mathrm{CCN}$ to cases in the tenuous cloud regime $\left(\mathrm{CCN}<10 \mathrm{~cm}^{-3}\right)$ will have a net warming effect, while adding $\mathrm{CCN}$ to cases with $\mathrm{CCN}>10 \mathrm{~cm}^{-3}$ will have a net cooling effect. Hence the net effect of an increased aerosol loading is the combined result of these two competing effects. Results from ASCOS and three previous experiments in the central Arctic Ocean (Bigg et al., 1996; Bigg and Leck, 2001) show that the CCN concentration frequently fall within the tenuous cloud regime (Fig. 6a). Apart from these four experiments observed $\mathrm{CCN}$ number concentrations are scarce in the central Arctic Ocean. We estimate the aerosol indirect effect by projecting the observed $\mathrm{CCN}$ values on the modeled cloud forcing curves (Fig. 2, thick solid lines). The CCN distributions are altered in three different scenarios to explore how different modifications affect the mean cloud forcing: Adding a single $\mathrm{CCN}$ per $\mathrm{cm}^{3}$ to each sample gives a relatively strong impact in the longwave 

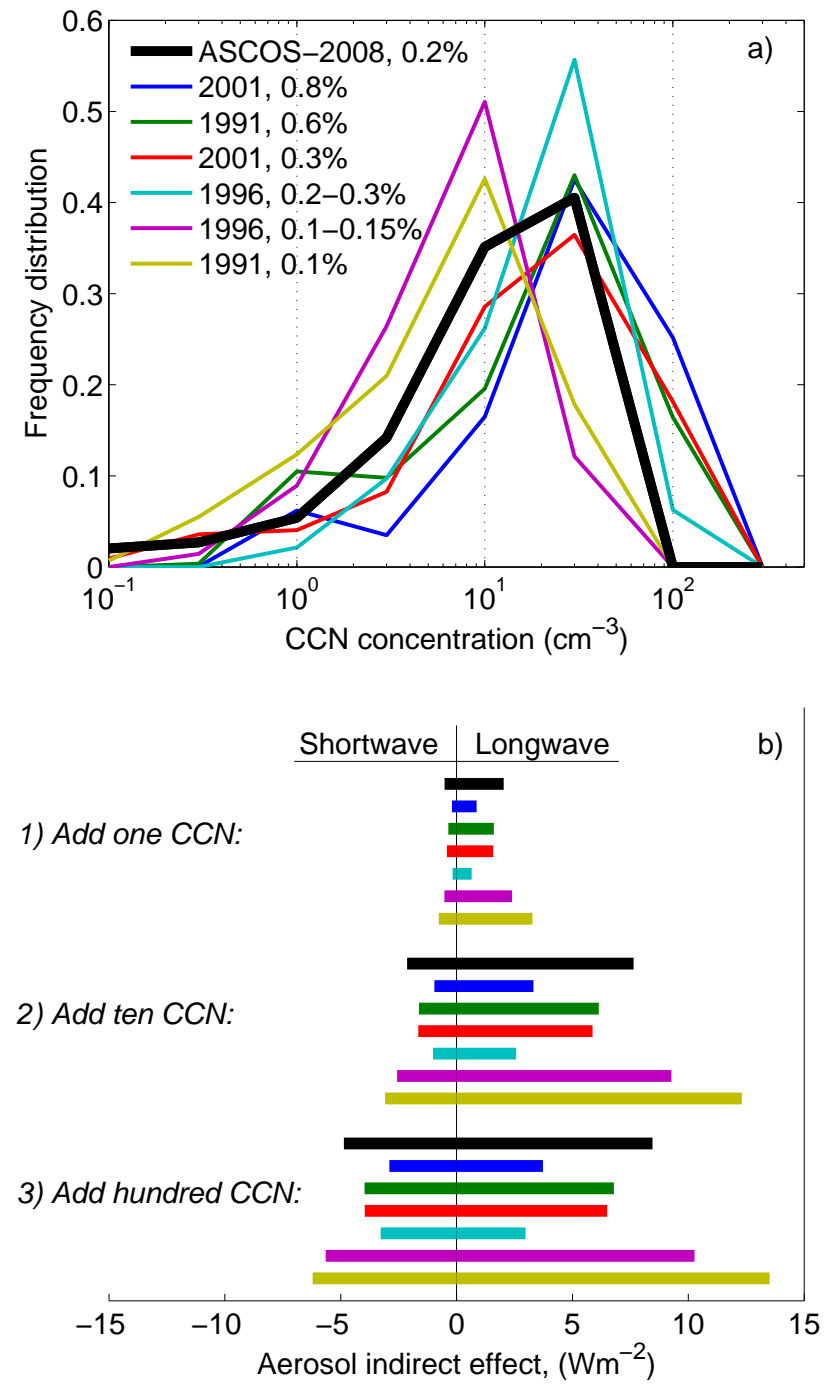

Fig. 6. Aerosol indirect effect impact estimates. Panel (a) displays frequency distributions of CCN from ASCOS and three earlier expeditions measured at different supersaturations as indicated in the legend. The expeditions were all conducted during the summer season in approximately the same area. (b) Impact estimates in three scenarios of changes to the $\mathrm{CCN}$ distributions under conditions found during ASCOS. The estimates are sorted according to applied supersaturation.

cloud forcing, while adding ten $\mathrm{CCN}$ essentially erodes the tenuous cloud regime, saturating the longwave cloud forcing, further adding a hundred $\mathrm{CCN}$ enhances primarily the shortwave cooling (Fig. 6b). The cases that exhibit the largest aerosol indirect effects are the ones that have the lowest $\mathrm{CCN}$ number concentrations. Across nearly all expeditions, applied supersaturations and scenarios, the aerosol indirect longwave warming effect equals, or exceeds the shortwave cooling effect.
The relative strength of the shortwave cooling to longwave warming depends critically on the solar zenith angle and surface reflectivity. During the peak melting season, June to July, when solar input is larger and surface reflectivity is lower due to melting, the shortwave cooling effect from adding $\mathrm{CCN}$ is likely more important relative to the longwave warming compared to ASCOS. Later in autumn and during spring, when the sun is lower and the surface reflectivity is high, the shortwave indirect effect is smaller than during ASCOS. During the Polar winter, clouds are predominantly mixed-phase, or entirely ice clouds making our estimates based on liquid clouds less relevant. A relative increase in ice nuclei may cause a more effective frozen precipitation formation at the expense of cloud water and water vapor (Curry, 1995; Lohmann and Feichter, 2005; Prenni et al., 2007). Even though the shortwave effect is naturally zero as the sun is below the horizon and therefore all aerosol direct and indirect effects must act in longwave radiation, the sign of the aerosol indirect effect during the Arctic winter is probably not only dependent on the $\mathrm{CCN}$ concentration, but likely also on the aerosol composition and other factors. While the local Arctic aerosol indirect effect may well be warming, the global effect is most likely cooling. And, as the Arctic climate tends to change roughly in concert with, but twice as fast as the global mean (Serreze and Francis, 2006), partly due to advection of heat and moisture from lower latitudes (Graversen, 2006), it remains an open question whether the total impact in the Arctic is dominated by the local surface warming, or the global cooling.

\section{Concluding remarks}

We have identified a tenuous cloud regime at low $\mathrm{CCN}$ concentrations, where cloud formation - and hence cloud forcing - is limited by the CCN availability. A simple way of modeling the tenuous cloud regime, by limiting the cloud liquid by a threshold droplet effective radius, is found to be in good agreement with observed cloud forcing from the central Arctic Ocean. Measurements of $\mathrm{CCN}$ from four expeditions confirms that the tenuous cloud regime is frequently observed in this region. These low values of $\mathrm{CCN}$ are suggested to be the combined result of weak local aerosol sources, effective wet deposition in the moist Arctic environment, and interactions between aerosol, cloud and precipitation.

The local impact of an increased aerosol loading in the Arctic is the non-linear result of competing cooling and warming aerosol indirect effects. For the late summer and early freeze-up we find a net aerosol induced warming for a wide range of assumptions. We argue that the year-mean effect is likely a climatologically significant surface warming, while in the peak melting season aerosol indirect effects may be cooling. The sign and strength of the estimated aerosol indirect effect depends critically on the surface reflectivity: In a warming climate, the Arctic surface reflectivity is likely to 
decrease as the snow and ice is projected to retreat, resulting in a shift in the aerosol indirect effect in the Arctic towards cooling in the melting season.

Given the strong observed aerosol indirect effects in the Arctic region, further research should be conducted to quantify the anthropogenic contribution to the natural Arctic background aerosol; the impacts of anthropogenic aerosol sources such as increased Arctic ship traffic and long-range pollution transport should be carefully assessed and monitored. With the projected increase of open water in the future the emissions of primary marine particles, both biogenic and sea-salt, is likely to increase, which may promote higher CCN number concentration (Bigg and Leck, 2008; Struthers et al., 2010). A controversial hypothesis states that an increase in biological aerosol sources in a warming climate is to moderate global climate change (Shaw, 1983; Charlson et al., 1987; Ayers and Cainey, 2007; Leck and Bigg, 2008). Provided that primary aerosol sources actually increase in a warming Arctic climate, the here suggested mechanism may well lead to a further enhancement of the warming. It remains, however, an open question whether the Arctic climate is impacted mostly by these local- or by the global aerosol indirect effects.

Acknowledgements. We are grateful to Douglas Orsini, Bjorn Stevens, Lee Raymond and many others for practical and scientific input. This study was supported by the Max Planck Society. ASCOS is funded by the Swedish Research Council, the Knut and Alice Wallenberg Foundation, DAMOCLES (EU 6th Framework Program), the US National Science Foundation and the Natural Environmental Research Council. We are grateful for logistical support from the Swedish Polar Research Secretariat, and to Oden's Captain Mattias Peterson and his crew.

The service charges for this open access publication have been covered by the Max Planck Society.

Edited by: G. de Leeuw

\section{References}

Ackerman, A. S., Toon, O. B., and Hobbs, P. V.: Reassessing the dependence of cloud condensation nucleus concentration on formation rates, Nature, 367, 445-447, 1994.

Ackermann, A. S., Kirkpatrick, M. P., Stevens, D. E., and Toon, O. B.: The impact of humidity above stratiform clouds on indirect aerosol climate forcing, Nature, 432, 1014-1017, 2004.

Albrecht, B.: Aerosols, cloud microphysics and fractional cloudiness, Science, 245, 1227-1230, 1989.

Ayers, G. P and Cainey, J. M.: The CLAW hypothesis: a review of the major developments, Environ. Chem., 4, 366-374, doi:10.1071/EN07080, 2007.

Baker, M. B. and Charlson, R. J.: Bistability of CCN concentrations and thermodynamics in the cloud-topped boundary layer, Nature, $345,142-145,1990$

Bigg, E. K. and Leck, C.: Cloud-active particles over the central Arctic Ocean, J. Geophys. Res., 106(D23), 32155-32166, 2001.
Bigg, E. K. and Leck, C.: The composition of fragments of bubbles bursting at the ocean surface, J. Geophys. Res., 113(D1), 1209, doi:10.1029/2007JD009078, 2008.

Bigg, E. K., Leck, C., and Nilsson, E. D.: Sudden changes in arctic atmospheric aerosol concentrations during summer and autumn, Tellus B, 48, 254-271, 1996.

Charlson, R. J., Lovelock, J. E., Andreae, M. O., and Warren, S. G.: Oceanic phytoplankton, atmospheric sulphur, cloud albedo and climate, Nature, 326, 655-661, 1987.

Covert, D. S., Wiedensohler, A., Aalto, P., Heintzenberg, J., McMurrry, P. H., and Leck, C.: Aerosol number size distributions from 3 to $500 \mathrm{~nm}$ diameter in the arctic marine boundary layer during summer and autumn, Tellus B, 48, 197-212, 1996.

Curry, J. A.: Interactions among turbulence, radiation and microphysics in Arctic stratus clouds, J. Atmos. Sci., 43, 90-106, 1986.

Curry, J. A.: Interactions among aerosols, clouds, and climate of the Arctic Ocean, Sci. Total Environ., 160/161, 777-791, 1995.

Curry, J. A. and Ebert, E. E.: Annual cycle of radiative properties of Arctic stratus clouds, J. Climate, 5, 1267-1280, 1992.

Curry, J. A. and Herman, G. F.: Infrared radiative properties of Arctic stratus clouds, J. Clim. Appl. Meteorol., 24, 525-538, 1985.

Fu, Q. and Liou, K. N.: On the Correlated k-Distribution Method for Radiative Transfer in Nonhomogeneous Atmospheres, J. Atmos. Sci., 49, 2139-2156, 1992.

Garrett, T. J. and Zhao, C.: Increased Arctic cloud longwave emmisivity associated with pollution from mid-latitudes, Nature, 440, 787-789, 2006.

Garrett, T. J., Radke, L. F., and Hobbs, P. V.: Aerosol effects on cloud emmissivity and surface longwave heating in the arctic, J. Atmos. Sci., 59, 769-778, 2002.

Gerber, H.: Microphysics of marine stratocumulus clouds with two drizzle modes, J. Atmos. Sci., 53, 1649-1662, 1996.

Graversen, R. G.: Do changes in the midlatitude circulation have any impact on the Arctic surface air temperature trend?, J. Climate, 19, 5422-5438, 2006.

Hu, Y. X. and Stamnes, K.: An accurate parameterization of the radiative properties of water clouds suitable for use in climate models, J. Climate, 6, 728-742, 1992.

Intrieri, J. M., Fairall, C. W., Shupe, M. D., Persson, P. O. G., Andreas, E. L., Guest, P. S., and Moritz, R. E.: An annual cycle of Arctic surface cloud forcing at SHEBA, J. Geophys. Res., 107(C10), doi:10.1029/2000JC000439, 2002.

Key, J. and Schweiger, A. J.: Tools for atmospheric radiative transfer: Streamer and FluxNet, Comput. Geosci., 24(5), 443-451, 1998.

Köhler, H.: The nucleus in and the growth of hygroscopic droplets, Trans. Far. Soc., 32, 1152-1161, 1936.

Lannerfors, H. Heintzenberg, J., and Hansson, H.-C.: A comprehensive study of physical and chemical parameters of of the Arctic summer aerosol results from the Swedish expedition Ymer80, Tellus B, 35, 40-54, 1983.

Leck, C. and Bigg, E. K.: A modified aerosol-cloud-climate feedback hypothesis, Environ. Chem., 4, 400-403, 2008.

Leck, C., Bigg, E. K., Covert, D. S., Heintzenberg, J., Maenhaut, W., Nilsson, E. D., and Wiedensohler, A.: Overview of the Atmospheric research program during the International Arctic Ocean Expedition 1991 (IAOE-91) and its scientific results, Tellus B, 48, 136-155, 1996. 
Leck, C., Nilsson, E. D., Bigg, K., and Bäcklin, L.: The Atmospheric program on the Arctic Ocean Expedition in the summer of 1996 (AOE-96) - A Technical Overview- Outline of experimental approach, instruments, scientific objectives, J. Geophys. Res., 106(D23), 32051-32067, 2001.

Leck, C., Norman, M., Bigg, E. K., and Hillamo, R.: Chemical composition and sources of the high Arctic aerosol relevant for fog and cloud formation, J. Geophys. Res., 107, D12, 4135, doi::10.1029/2001JD001463, 2002.

Leck, C., Tjernström, M., Matrai, P., Swietlicki, E., and Bigg, E. K.: Can marine micro-organisms influence melting of the Arctic pack ice?, Eos 85(3), 25-36, 2004.

Lee, R. L.: Mie theory, Airy theory, and the natural rainbow, Appl. Opt., 37(9), 1506-1519, 1998.

Lohmann, U. and Feichter, J.: Global indirect aerosol effects: a review, Atmos. Chem. Phys., 5, 715-737, doi:10.5194/acp-5-7152005, 2005.

Lohmann, U. and Leck, C.: Importance of submicron surface-active organic aerosols for pristine Arctic clouds, Tellus B, 57, 261268, 2005.

Lu, M. L. and Seinfeld, J. H.: Study of the aerosol indirect effect by large-eddy simulation of marine stratocumulus, J. Atmos. Sci., 62, 3909-3932, 2005.

Lubin, D. and Vogelmann, A. M.: A climatologically significant aerosol longwave indirect effect in the Arctic, Nature, 439, 453456, 2006

Lubin, D. and Vogelmann, A. M.: Expected magnitude of the aerosol shortwave indirect effect in the springtime Arctic liquid water clouds, Geophys. Res. Lett., 34, L11801, doi:10.1029/2006GL028750, 2007.

Moran, K. P., Martner, B. E., Post, M. J., Kropfli, R. A., Welsh, D. C., and Widener, K. B.: An unattended cloud-profiling radar for use in climate research, B. Am. Meteor. Soc., 79, 443-455, 1998.

Petters, M. D., Snider, J. R., Stevens, B., Vali, G., Faloona, I., and Russell, L.: Accumulation mode aerosol, pockets of open cells, and particle nucleation in the remote subtropical pacific marine boundary layer, J. Geophys. Res., 111, D02206, doi:10.1029/2004JD005694, 2006.

Pincus, R. and Baker, M. B.: Effect of precipitation on the albedo susceptibility of clouds in the marine boundary layer, Nature, 372, 250-252, 1994.

Prenni, A. J., DeMott, P. J., Kreidenweis, S. M, Harrington, J. Y., Avramov, A., Verlinde, J., Tjernström, M., Long, C. N., and Olsson, P. Q.: Can Ice-Nucleating Aerosols Affect Arctic Seasonal Climate?, B. Am. Meteor. Soc., 88, 541-550, 2007.

Ramanathan, V., Cess, R. D., Harrison, E. F., Minnis, P., Barkstrom, B. R., Ahmed, E., and Hartmann, D.: Cloud-radiative forcing and climate: Results from the Earth Radiation Budget Experiment, Science, 243, 57-63, 1989 .

Ramanathan, V., Crutzen, P. J., Kiehl, J. T., and Rosenfeld, D.: Aerosols, climate and the hydrological cycle, Science, 294, 2119-2124, 2001.

Roberts, G. C. and Nenes, A. A: continuous-flow streamwise thermal-gradient $\mathrm{CCN}$ chamber for atmospheric measurements, Aerosol Sci. Technol., 39, 206-221, 2005.

Rosenfeld, D., Lohmann, U., Raga, G. B., O'Dowd, C. D., Kulmala, M., Fuzzi, S., Reissell, E., and Andreae, M. O.: Flood or drought: How do aerosols affect precipitation?, Science, 321, 1309-1313, 2008.
Rotstayn, L. D. and Penner, J. E.: Indirect aerosol forcing, quasiforcing and climate response, J. Climate, 14, 2960-2975, 2001.

Sandu, I., Brenguier, J.-L., Geoffroy, O., Thouron, O., and Masson, V.: Aerosol impacts on the diurnal cycle of marine stratocumulus, J. Atmos. Sci., 65, 2705-2718, 2008.

Schneider, S. H.: Cloudiness as a global climate feedback mechanism: The effects on the radiation balance and surface temperature of variations in cloudiness, J. Atmos. Sci., 29, 1413-1422, 1972.

Sedlar, J., Tjernström, M., Mauritsen, T., Shupe, M., Brooks, I. M., Birch, C., Leck, C., Sirevaag, A., Persson, P. O. G., and Nicolaus, M.: A transitioning Arctic surface energy budget: the impacts of solar zenith angle, surface albedo and cloud radiative forcing, Clim. Dynam., doi:10.1007/s00382-010-0937-5, 2010.

Serreze, M. C. and Francis, J.: The Arctic amplification debate, Clim. Change, 76, 241-264, 2006.

Shaw, G. E.: Biocontrolled thermostasis involving the sulfur cycle, Clim. Change, 5, 297-303, 1983.

Shupe, M. D., Daniel, J. S., De Boer, G., Eloranta, E. W., Kollias, P., Long, C. N. Luke, E. P., Turner, D. D., and Verlinde, J. A: Focus on mixed-phase clouds: The status of ground-based observational methods, B. Ame. Meteor. Soc., 89, 1549-1562, 2008.

Solomon, S., Qin, D., Manning, M., Chen, Z., Marquis, M., Averyt, K. B., Tignor, M., and Miller, H. L.: Climate change 2007 The physical science basis, Cambridge University Press, 996 pp., 2007.

Stevens, B. and Feingold, G.: Untangling aerosol effects on clouds and precipitation in a buffered system, Nature, 461, 607-613, 2009.

Stevens, B., Vali, G., Comstock, K., Wood, R., van Zanten, M. C., Austin, P. H., Bretherton, C. S., and Lenschow, D. H.: Pockets of open cells (POCs) and drizzle in marine stratocumulus, B. Am. Meteor. Soc., 86, 51-57, 2005.

Struthers, H., Ekman, A. M. L., Glantz, P., Iversen, T., Kirkevåg, A., Mårtensson, E. M., Seland, Ø., and Nilsson, E. D.: The effect of sea ice loss on sea salt aerosol concentrations and the radiative balance in the Arctic, Atmos. Chem. Phys. Discuss., 10, 28859 28908, doi:10.5194/acpd-10-28859-2010, 2010.

Tjernström, M., Leck, C., Persson, P. O. G., Jensen, M. L., Oncley, S. P., and Targino, A.: The Summertime Arctic Atmosphere: Meteorological measurements during the Arctic Ocean Experiment 2001 (AOE-2001), B. Am. Meteor. Soc., 85, 1305-1321, 2004.

Twomey, S. A.: The influence of pollution on the shortwave albedo of clouds, J. Atmos. Sci., 34, 1149-1152, 1977.

Verlinde, J., Harrington, J. Y., Yannuzzi, V. T., Avramov, A., Greenberg S., Richardson, S. J., Bahrmann, C. P., McFarquhar, G. M., Zhang, G., Johnson, N., Poellot, M. R., Mather, J. H., Turner, D. D., Eloranta, E. W., Tobin, D. C., Holz, R., Zak, B. D., Ivey, M. D., Prenni, A. J., DeMott, P. J., Daniel, J. S., Kok, G. L., Sassen, K., Spangenberg, D., Minnis, P., Tooman, T. P., Shupe, M., Heymsfield, A. J., and Schofield, R.: The Mixed-Phase Arctic Cloud Experiment (M-PACE), B. Am. Meteor. Soc., 88, 205221, doi:10.1175/bams-88-2-205, 2007.

Walsh, J. E. and Chapman, W. L. Arctic cloud-radiationtemperature associations in observational data and atmospheric reanalysis, J. Climate, 11, 3030-3045, 1998.

Westwater, E. R., Han, Y., Shupe, M. D., and Matrosov, S. Y. Analysis of integrated cloud liquid and precipitable water vapor 
retrievals from microwave radiometers during SHEBA, J. Geophys. Res., 106, 32019-32030, 2001.

Wood, R., Comstock, K. K., Bretherton, C. S., Cornish, C., Tomlinson, J., Collins, D. R., and Fairall, C.: Open cellular structure in marine stratocumulus sheets. J. Geophys. Res. 113, D12207, doi:10.1029/2007JD009371, 2008.
Zhou, J., Swietlicki, E., Berg, O. H., Aalto, P. P., Hämeri, K., Nilsson, E. D., and Leck, C. Hygroscopic properties of aerosol particles over the central Arctic Ocean during summer, J. Geophys. Res., 106(D23), 32111-32123, 2001. 